\title{
JUMLAH RERATA TROMBOSIT DAN PLATELETCRIT (MPV DAN PCT) SEBAGAI PREDIKTOR SYOK PADA ANAK YANG TERINFEKSI DENGUE DI RS Dr. SAIFUL ANWAR MALANG
}

\author{
Asri Prameswari ${ }^{\star 凶}$, Agustin Iskandar**, Muhammad Wafi' ${ }^{\star * *}$
}

\begin{abstract}
Abstrak
Trombosit memegang peran penting pada patogenesis demam berdarah dengue (DBD), fungsi utama trombosit adalah pembentukan sumbat mekanik selama respons hemostasis normal terhadap cedera vaskuler. Gangguan pada trombosit baik jumlah maupun fungsi dapat mengakibatkan kebocoran darah spontan melalui pembuluh darah kecil. Jumlah rerata trombosit dan platelet crit (MPV dan PCT) diduga dapat dijadikan sebagai prediktor syok pada anak yang terinfeksi dengue. Penelitian ini bertujuan untuk mengetahui apakah jumlah rerata trombosit dan plateletcrit (MPV dan PCT) dapat dijadikan sebagai prediktor syok pada anak yang terinfeksi dengue di RS. Dr. Saiful Anwar Malang. Penelitian ini menggunakan metode kohort retrospektif dengan pengambilan rekam medis subjek anak yang dirawat dari bulan Januari 2016-April 2017 dengan metode consecutive sampling dan memenuhi kriteria untuk didiagnosis sebagai infeksi dengue. Diperoleh 39 data pasien anak yang terinfeksi dengue dengan rincian 21 sampel syok dan 18 sampel nonsyok. Dengan analisis kurva ROC diketahui bahwa anak yang terinfeksi dengue dengan jumlah trombosit $<50.000$ mempunyai risiko mengalami syok 2,32 kali lebih besar dengan nilai sensitifitas $44,4 \%$ dan spesifitas $90,48 \%$. Pada anak yang terinfeksi dengue dengan nilai MPV $>9,7$ mempunyai risiko mengalami syok 1,5 kali lebih besar dengan nilai sensitifitas $83,33 \%$ dan spesifitas $28,57 \%$. Pada anak yang terinfeksi dengue dengan nilai PCT $<0,14$ mempunyai risiko mengalami syok 9,52 lebih besar dengan nilai sensitifitas 94,44\% dan spesifitas 61,9\%. Dapat disimpulkan bahwa MPV dan PCT dapat dipakai sebagai indikator prognosis terjadinya dengue shock syndrome.
\end{abstract}

Kata kunci: dengue shock syndrome, jumlah trombosit, MPV, PCT.

\section{MEAN PLATELETS VOLUME AND PLATELETCRIT (MPV AND PCT) AS SHOCK PREDICTOR IN DENGUE-INFECTED CHILDREN AT Dr. SAIFUL ANWAR HOSPITAL MALANG}

\begin{abstract}
Platelets hold an important role in the pathogenesis of dengue hemorrhagic fever (DHF). The main function of platelets is the formation of mechanical plugs during normal hemostasis response to vascular injury. Disorder of platelets, both the numbers and functions cause spontaneous blood leakage through small blood vessel. Mean platelets volume and plateletcrit (MPV and PCT) are expected to be the predictors of shock in dengue-infected children. This research aimed to find out whether mean platelets volume and plateletcrit (MPV and PCT) as the predictors of shock in dengue-infected children at Dr. Saiful Anwar hospital Malang. The research design used was retrospective cohort. The data was taken from patient's medical records from January 2016 to April 2017 with consecutive sampling and diagnosed as dengue infection. There were 39 data of dengue-infected children in which the 21 samples are considered as shock while the other 18 samples are non-shock. By ROC curve analysis in dengue-infected children, it was showed that platelets count of $<50,000$ have a risk of shock 2.32 times greater with sensitivity value $44.4 \%$ and specificity $90.48 \%$. In dengue-infected children with MPV value of $>9.7$, have a risk of shock 1.5 times greater with sensitivity value $83.33 \%$ and specificity $28.57 \%$ and the PCT value of $<0.14$ in dengue-infected children have a risk of shock 9.52 times greater with sensitivity value $94.44 \%$ and specificity $61.9 \%$. It can be concluded that MPV and PCT can be used as the prognostic indicator of dengue shock syndrome.
\end{abstract}

Keywords: Dengue shock syndrome, MPV, PCT, platelets count.

* Departemen IImu Penyakit Dalam, Fakultas Kedokteran Universitas Brawijaya-RS. Dr. Saiful Anwar Malang

${ }^{*}$ Departemen Parasitologi, Fakultas Kedokteran Universitas Brawijaya Malang

***Jurusan Pendidikan Dokter, Fakultas Kedokteran Universitas Brawijaya Malang

区E-mail: asriprameswari@gmail.com 


\section{Pendahuluan}

Demam berdarah dengue (DBD) atau dengue hemorrhagic fever (DHF) merupakan salah satu penyakit yang perjalanan penyakitnya cepat dan dapat menyebabkan kematian dalam waktu singkat. ${ }^{1}$ Kementerian Kesehatan RI mencatat jumlah penderita DBD di Indonesia pada bulan JanuariFebruari 2016 sebanyak 8.487 orang penderita DBD dengan jumlah kematian 108 orang. Golongan terbanyak yang mengalami DBD di Indonesia pada usia 5-14 tahun mencapai $43,44 \%$ dan usia 15-44 tahun mencapai $33,25 \% .{ }^{2}$ World Health Organization (WHO) menetapkan kriteria diagnosis DBDyaitu: demam akut; manifestasi perdarahan, tes torniket positif; pembesaran hepar; trombositopenia 100.000 sel per mikroliter; hemokonsentrasi, peningkatan hematokrit 20\%. Dengue berat berpotensi mengalami komplikasi hingga kematian yang diakibatkan oleh kebocoran plasma, akumulasi cairan, distress nafas, perdarahan berat, gangguan organ hingga syok. ${ }^{3}$

Trombosit dihasilkan dalam sumsum tulang tulang melalui fragmentasi sitoplasma megakariosit. Fungsi utama trombosit adalah membentuk sumbat mekanik selama respons hemostasis normal terhadap cedera vaskuler. Tanpa trombosit,dapat terjadi kebocoran darah spontan melalui pembuluh darah kecil. Reaksi trombosit berupa adhesi, sekresi, agregasi, dan fusi serta aktivitas prokoagulannya sangat penting. ${ }^{4}$

Penggunaan parameter untuk mengetahui disfungsi atau aktivasi trombosit seperti B-thromboglobulin, platelet factor 4, ekspresi P-selectin, atau angiopoietin masih tergolong mahal dan penggunaan dalam pelayanan rumah sakit masih terbatas. Mean platelet volume (MPV) merupakan rerata jumlah trombosit yang menggambarkan fungsi dan aktifitas trombosit. Semakin tinggi MPV mengindikasikan banyaknya trombosit berukuran besar yang merupakan tanda dari peningkatan pergantian trombosit. ${ }^{5}$

Plateletcrit (PCT) adalah parameter untuk mendeteksi proporsi volume seluruh darah yang ditempati oleh trombosit. ${ }^{6}$ Pada pasien dengue fever ditemukan nilai MPV, PCT, dan jumlah trombosit cenderung menurun. Namun pada DBD ditemukan nilai MPV cenderung meningkat meskipun dalam batas normal sedangkan nilai PCT dan jumlah trombositnya menurun. ${ }^{7}$

World Health Organization (WHO) tahun 2011 menetapkan kriteria derajat keparahan dengue sebagai acuan bagi klinisi dalam menentukan prognosis pasien dengue. Namun dengan manifestasi klinis yang sangat bervariasi, patogenesis yang kompleks, dan perbedaan serotipe virus pada daerah yang berbeda, menyulitkan prediksi perjalanan penyakit serta penilaian apakah pasien akan mengalami syok atau syok berulang. ${ }^{8}$ Oleh karena itu, peneliti ingin mengetahui MPV dan PCTsebagai prediktor syok pada pasien anak yang terinfeksi dengue.

\section{Bahan dan Metode}

Penelitian ini adalah penelitian retrospektif dari rekam medis pasien anak dengan infeksi dengue pada periode Januari 2016 hingga April 2017 di Rumah Sakit Dr. Saiful Anwar Malang dengan teknik pengambilan sampel adalah consecutive sampling. Penelitian ini telah disetujui oleh Komite Etik Penelitian di Fakultas Kedokteran Universitas Brawijaya Malang.

Kriteria inklusi adalah pasien anak usia 0 - 15 tahun yang didiagnosis secara klinis demam dengue atau demam berdarah dengue dengan hasil laboratorium Ns-1 (+), IgM anti-dengue $(+)$, dan IgG anti-dengue $(+)$ dan dilakukan pemeriksaan darah lengkap rutin, jumlah trombosit, MPV dan PCT di laboratorium RS. Dr. Saiful Anwar Malang sesuai dengan indikasi medis pasien. 
Subjek penelitian dibagi menjadi 2 kelompok, yaitu kelompok pasien yang mengalami dengue shock syndrome (DSS) dan yang tidak, didiagnosis menurut klasifikasi WHO tahun 2011, DSS adalah derajat III dan IV, serta pasien yang mengalami expanded dengue syndrome, sedangkan pasien yang non DSS adalah derajat I dan II.

Analisis statistik dengan ujit-test untuk memeriksa adanya perbedaan antara jumlah trombosit, MPV, dan PCT pada pasien yang syok dan non-syok. Nilai p bermakna apabila nilai $p<0.05$. Analisis statistik dengan melakukan uji dengan kurva ROC dan relative risk untuk melihat prognostik jumlah trombosit, MPV, dan PCT sebagai prediktor syok pada infeksi Dengue. ${ }^{9,10}$

Alur penelitian dapat dilihat pada Gambar 1.

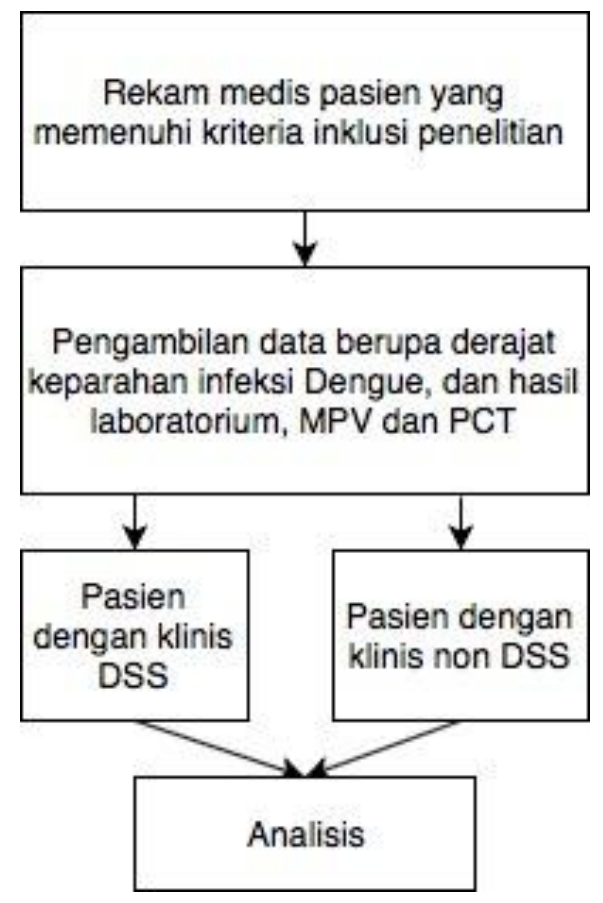

Gambar 1. Data rekam medis yang memenuhi kriteria inklusi
Data rekam medis yang dikumpulkan berupa data klinis, hasil laboratorium dan keluaran klinis untuk dilakukan analisis. Data laboratorium jumlah trombosit, MPV dan PCT yang diambil yaitu pada pemeriksaan laboratorium hari 1 (MPV, PCT), dan pada pemeriksaan hari berikutnya (jumlah trombosit1, MPV1, PCT1) serta perbedaan hasil laboratorium (delta jumlah trombosit, delta MPV dan delta PCT).

\section{Hasil}

Pada Tabel 1 dan Tabel 2 disajikan karakteristik pasien pada penelitian ini.

Analisis Statistik

Hasil analisis uji t-test (Tabel 3) menunjukkan bahwa jumlah trombosit, MPV, dan PCT dengan prognosis dengue menunjukkan perbedaan yang berarti untuk jumlah trombosit pada pasien yang mengalami DSS dan non DSS. Namun, pada delta jumlah trombosit, delta MPV, dan delta PCT menunjukkan tidak ada perbedaan bermakna antara kelompok DSS dan non DSS.

Uji prognosis menggunakan kurva ROC dengan confidence level $95 \%$ didapatkan nilai area under the curve (AUC) tiap parameter pada Tabel 4. Parameter yang memiiki AUC di atas 50\% yaitu MPV1, PCT1, delta jumlah trombosit, delta MPV, delta PCT (Tabel 4).

Selanjutnya, dengan menggunakan analisis Odds ratio (relative risk) pada confidence level 95\%, ditentukan nilai standar cut off jumlah trombosit $50.000 \mathrm{~mm}^{3}$, nilai cut off 9,7 untuk MPV dan nilai cut off 0,14 untuk PCT sebagai prediktor pada anak yang terinfeksi dengue terhadap terjadinya DSS dan non DSS. ${ }^{11,12}$ Pada penelitian ini, delta trombosit didapatkan cut off optimal sebesar $16.000 / \mu$ l dengan sensitifitas $66,7 \%$ dan spesifitas $71,43 \%$, delta MPV didapatkan cut off optimal 0,8 dengan 
sensitifitas $44,44 \%$ dan spesifitas $85,71 \%$

(Tabel 5).

Tabel 1. Karakteristik pasien

\begin{tabular}{lcc}
\hline \multicolumn{1}{c}{ Karakteristik } & Jumlah $(\mathrm{n})$ & Persentase $(\%)$ \\
\hline $\begin{array}{l}\text { Jenis Kelamin } \\
\text { Laki-laki }\end{array}$ & 17 & 43,59 \\
$\begin{array}{l}\text { Perempuan } \\
\text { Usia (tahun) }\end{array}$ & 22 & 56,41 \\
$0-3$ & 14 & \\
$3-6$ & 8 & 35,90 \\
$6-9$ & 5 & 20,51 \\
$9-12$ & 8 & 12,82 \\
$12-15$ & 4 & 20,51 \\
\hline
\end{tabular}

Tabel 2. Karakteristik klinis pasien

\begin{tabular}{lcc}
\hline Karakteristik & DSS & Non DSS \\
\hline Derajat Keparahan & $\mathrm{n}=21 ;(53,85 \%)$ & $\mathrm{n}=18 ;(46,15 \%)$ \\
Rerata Trombosit & $65,333 \times 10^{3} / \mathrm{uL}$ & $193,906 \times 10^{3} / \mathrm{uL}$ \\
Rerata MPV & 10,98 & 10,28 \\
Rerata PCT & 0,07 & 0,18
\end{tabular}

Tabel 3. Hasil uji t-test tiap parameter

\begin{tabular}{lc}
\hline \multicolumn{1}{c}{ Parameter } & Nilai p \\
\hline Jumlah trombosit 1 & 0,000 \\
MPV1 & 0,039 \\
PCT1 & 0,000 \\
Delta jumlah trombosit & 0,062 \\
Delta MPV & 0,743 \\
Delta PCT & 0,192 \\
\hline${ }^{*}<<05,95 \%$ confidence interval
\end{tabular}

${ }^{*} p<0,05,95 \%$ confidence interval

Tabel 4. Nilai AUC tiap parameter

\begin{tabular}{lc}
\hline \multicolumn{1}{c}{ Parameter } & Nilai AUC \\
\hline Jumlah Trombosit1 & $45,2 \%$ \\
MPV1 & $69,6 \%$ \\
PCT1 & $65,9 \%$ \\
Delta Trombosit & $66,4 \%$ \\
Delta MPV & $52,8 \%$ \\
Delta PCT & $69,2 \%$ \\
\hline
\end{tabular}


Tabel 5. Hasil penghitungan relative risk

\begin{tabular}{lccc}
\hline \multicolumn{1}{c}{ Parameter } & Relative Risk & Sensitivitas & Spesifitas \\
\hline Jumlah Trombosit1 & 2,32 & $44,4 \%$ & $90,48 \%$ \\
\hline MPV1 & 1,5 & $83,33 \%$ & $28,57 \%$ \\
PCT1 & 9,52 & $94,44 \%$ & $61,9 \%$ \\
\hline Delta Jumlah Trombosit & 2,33 & $66,67 \%$ & $71,43 \%$ \\
\hline Delta MPV & 2,03 & $44,44 \%$ & $85,71 \%$ \\
Delta PCT & 2,47 & $72,22 \%$ & $66,67 \%$ \\
\hline
\end{tabular}

\section{Pembahasan}

Hasil penelitian menunjukkan bahwa pasien anak yang terinfeksi dengue dengan jumlah trombosit di bawah 50.000/uL mempunyai kemungkinan 2,32 lebih besar mengalami DSS dengan nilai sensitivitas $44,4 \%$ dan spesifitas $90,48 \%$. Hal tersebut sesuai dengan penelitian Kan di Manado yaitu jumlah trombosit anak yang mengalami DSS berkisar $20.000-50.000$ $\mathrm{mm}^{3} .{ }^{13}$

Penurunan jumlah trombosit pada pasien dengue secara imunologi merupakan akibat dari aktifasi komplemen oleh kompleks imun yang menyebabkan terbentuknya C3a dan C5a dan memicu plasma leakage, kemudian terjadi agregasi platelet, selanjutnya platelet ini akan dihancurkan oleh RES dan menyebabkan penurunan jumlah trombosit.

Hasil penelitian ditemukan bahwa pasien anak yang terinfeksi dengue dengan nilai PCT di bawah 0,14 mempunyai kemungkinan 9,52 kali lebih besar akan mengalami DSS dengan nilai sensitivitas $94,44 \%$ dan spesifitas $61,9 \%$.

Plateletcrit (PCT) adalah parameter untuk mendeteksi proporsi volume seluruh darah yang ditempati oleh trombosit. Plateletcrit dipengaruhi oleh jumlah trombosit. Pada infeksi dengue terjadi penurunan trombosit sehingga nilai plateletcrit akan cenderung mengalami penurunan. Pada pasien DSS nilai trombosit berkisar antara $20.000-50.000 / u L$, sehingga pada penelitian ini plateletcrit mengalami penurunan. ${ }^{13}$

Hasil penelitian menunjukkan bahwa pasien anak yang terinfeksi dengue dengan nilai MPV di atas 9,7 mempunyai kemungkinan 1,5 kali lebih besar mengalami DSS dengan sensitivitas $83,33 \%$ dan spesifitas $28,57 \%$. Hal ini sesuai dengan penelitian yang dilakukan oleh Septin, yaitu hasil MPV di atas 9,7 mempunyai kemungkinan 4,8 kali lebih besar mengalami DSS daripada pasien yang MPV di bawah $9,7 .{ }^{14}$

Mean platelet volume (MPV) merupakan rerata volume trombosit yang menggambarkan fungsi dan aktifitas trombosit, yaitu semakin tinggi MPV mengindikasikan banyaknya trombosit berukuran besar yang merupakan tanda dari peningkatan pergantian trombosit. ${ }^{5}$ Akibat destruksi platelet yang berlebihan maka akan terjadi kompensasi dengan pengeluaran megakariosit yang masih muda untuk keluar dini, hal inilah yang menyebabkan peningkatan nilai MPV.

Hasil penelitian menunjukkan bahwa nilai PCT kurang dari 0,14 lebih sensitif sebagai prediktor syok dengan nilai $94,44 \%$, daripada MPV di atas 9,7 dengan nilai sensitifitas $83,33 \%$. Respons imun yang diketahui berperan dalam patogenesis dengue yang pertama adalah hipotesis antibody dependent enhancement yaitu respons humoral berupa pembentukan antibodi yang berperan dalam netralisasi 
virus, sitolisis, yang dimediasi komplemen dan sitotoksisitas yang dimediasi antibodi. Antibodi terhadap virus dengue berperan dalam mempercepat replikasi virus pada monosit atau makrofag. Limfosit $\mathrm{T}$ baik $\mathrm{T}$ helper $\left(\mathrm{CD}_{4}\right)$ dan $\mathrm{T}$ sitotoksik $\left(\mathrm{CD}_{8}\right)$ berperan dalam respons imun seluler terhadap virus dengue. Diferensiasi T-helper yaitu Th1 akan memproduksi interferon gamma, IL-2 dan limfokin, sedangkan Th2 memproduksi IL-4, IL-5, IL-6 dan IL-10. Monosit dan makrofag berperan dalam fagositosis virus dengan opsonisasi antibodi. Namun, proses fagositosis ini menyebabkan peningkatan replikasi virus dan sekresi sitokin oleh makrofag. Selain itu, aktivitasi komplemen oleh kompleks imun menyebabkan terbentuknya C3a dan C5a. Titer IgM antiplatelet terlihat tinggi pada pasien DBD dan atau yang mengalami DSS jika dibandingkan dengan pasien demam dengue. Antibodi antiplatelet inilah yang diduga menyebabkan platelet lisis. $15,16,17$

Pada hasil uji delta jumlah trombosit ditemukan bahwa pasien dengan peningkatan jumlah trombosit lebih dari 16.000/ $\mathrm{L}$ mempunyai risiko terjadi DSS 2,33 kali lebih besar daripada pasien dengan peningkatan jumlah trombosit di bawah 16.000/ $\mathrm{L}$ atau penurunan jumlah trombosit dengan nilai sensitivitas $66,67 \%$ dan spesifitas $71,43 \%$. Pada pasien dengan peningkatan PCT lebih dari 0,01 memiliki risiko terjadi DSS 2,47 kali lebih besar daripada pada pasien yang tidak mengalami peningkatan PCT dengan nilai sensitifitas $72,22 \%$ dan spesifitas $66,67 \%$. Dari hasil tersebut ditemukan bahwa peningkatan jumlah trombosit dan PCT semakin meningkatkan risiko terjadinya kejadian DSS. Hal ini diduga disebabkan oleh selisih hari pengambilan cek darah lengkap pada tiap pasien tidak sama, beberapa pasien yang pengambilan data awal dan berikutnya dengan rentang waktu lebih dari dua hari menyebabkan mayoritas perhitungan delta menjadi positif karena sudah ada perbaikan secara klinis, begitu pula dengan kondisi imunologi. Sementara pada beberapa pasien yang pengambilan data trombosit dan PCT dengan rentang waktu satu hari ditemukan penurunan jumlah trombosit sehingga anak yang mengalami penurunan trombosit akan memiliki risiko yang lebih besar terjadi DSS.

Diagnosis awal menentukan pola fluktuasi jumlah trombosit, yaitu rerata trombosit pada pasien demam dengue akan turun pada hari ke-4, terendah di hari ke-5 dan kembali naik pada hari selanjutnya. Pada DBD trombosit pasien mulai menurun pada hari ke-3, terendah di hari ke-5 dan akan mulai naik pada hari selanjutnya. Pada pasien DBD trombosit mulai turun pada hari ke-3, sedangkan puncaknya didapatkan pada hari ke-6 dan mulai meningkat pada hari selanjutnya. ${ }^{15}$ Pada penelitian ini terdapat perbedaan bermakna pada hari ke6 antara pasien DSS dan non DSS. Hal ini yang menyebabkan delta jumlah trombosit dan PCT menjadi positif karena hari ke-6 untuk pasien non DSS dan hari ke-7 untuk pasien DSS telah terlewati, sehingga trombosit sebagian besar pasien mengalami kenaikan. Sementara itu, pada delta MPV ditemukan bahwa pasien yang mengalami peningkatan MPV, maka cenderung mengalami DSS yaitu terjadi destruksi trombosit yang lebih banyak dibandingkan dengan supresi terhadap pembentukan trombosit.

Keterbatasan penelitian adalah data berasal dari rekam medis, sehingga bergantung pada kelengkapan pengisian status serta ketidakseragaman rentang waktu pengambilan darah rutin pada pasien dengue karena disesuaikan dengan indikasi dan kondisi medis pasien.

\section{Kesimpulan}

Berdasarkan hasil penelitian yang telah dilakukan, dapat disimpulkan bahwa MPV 
dan PCT dapat dijadikan sebagai prediktor syok pada kasus infeksi dengue pada anak. 1. Nilai MPV di atas 9,7 memiliki kemungkinan terjadi syok 1,5 kali lebih besar dengan nilai sensitivitas $83,33 \%$,

2. PCT di bawah 0,14 memiliki kemungkinan terjadi syok 9,52 kali lebih besar dengan nilai sensitivitas $94,44 \%$.

3. Jumlah trombosit di bawah $50.000 / \mu \mathrm{L}$ memiliki kemungkinan terjadi syok 2,32 lebih besar dengan spesifitas $90,48 \%$.

4. Delta MPV paling spesifik di antara delta jumlah trombosit dan delta PCT sebagai prediktor syok pada kasus infeksi dengue.

\section{Daftar Pustaka}

1. Kementerian Kesehatan Republik Indonesia. Demam Berdarah Dengue. Pusat Data dan Surveilans Epidemiologi. Jurnal Epidemiologi 2010. $2: 1-6$.

2. Kementerian Kesehatan Republik Indonesia. Wilayah KLB DBD ada di 11

Provinsi. 2016. (Online). http://www.depkes.go.id/article/print/160 30700001/wilayah-klb-dbd-ada-di-11provinsi.html.

3. Isselbacher KJ. Prinsip-Prinsip IImu Penyakit Dalam. Volume 2. Edisi 13. Jakarta: Penerbit Buku Kedokteran EGC. 2014.

4. Hoffbrand AV, JE Pettit, and PAH Moss. Essential Haematology. Fourth Edition. Oxford: Blackwell science. 2005.

5. Dewi SR. Analisis Indeks Trombosit Pada Pasien Infeksi dengue. FK UGM. Yogyakarta. 2015.

6. Khaleel KJ, Ahmed AA, and Anwar MA.. Platet indices. Karbala J Med. 2014; 7(2):1952-1958.

7. Hardeva RN, Shyam LM, Sahil PBK Gupta. Evaluation of Platelet Indices in Patients with Dengue Infections. International Journal of Scientific Research. 2016; 5(7).
8. World Health Organization-South East Asia Regional Office. Comprehensive Guidelines for Prevention and Control of Dengue and Dengue Hemorrhagic Fever. India: WHO. 2011. P.1-67.

9. Dahlan MS. Penelitian Prognostik dan Sistem Scoring: Disertai Praktik Dengan SPSS dan Stata. Seri 8. Jatinangor: Alqaprint Jatinangor. 2011.

10. Dahlan MS. Statistik untuk Kedokteran dan Kesehatan. Edisi ke-6. Jakarta: Epidemiologi Indonesia. 2014.

11. Heatubun CE. Perbandingan Jumlah Trombosit pada Demam Berdarah Dengue Tanpa Syok dan Syok di RSUP Prof. Dr. RD Kandou Manado. Jurnal eBiomedik. 2013; 1(2).

12. Fatimah S. Change in Platelet Count. Folia Medica Indonesiana. 2014; 50(1):34-36.

13. Septin W. Platelet Distributin Width (PDW) dan Mean Platelet Volume (MPV) Sebagai Prediktor Beratnya Demam Berdarah Dengue pada Anak. Surakarta: FK UNS. 2014.

14. Sari RC, Hartono K, Dwiyanti P. Pola Jumlah Trombosit Pasien Infeksi Virus Dengue yang Dirawat di SMF IImu Kesehatan Anak RSUD.Soetomo Surabaya. Surabaya: Departemen IImu Kesehatan Anak Fakultas Kedokteran Universitas Airlangga. 2017.

15. Cherry JD, et al. Feigin and Cherry's Textbook of Pediatric Infectious Diseases. Philadelphia: Elsevier Saunders. 2014.

16. Kliegman R, Stanton B, St Geme JW, Schor NF, and Behrman RE. Nelson Textbook of Pediatrics. Twentieth Edition. Philadelphia: Elsevier. 2016.

17. Halstead. Assesing The Prognosis of Dengue-infected Patients. Medicine Reports. 2009;1(73). 